\title{
舞踏鼠ノ聽神經中樞ノ病理 組織學的研究
}

\section{服 部 貴 芳}

[京都帝國大學醫學部耳悬咽喉科敎室(主任星野敎授)]

目

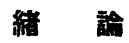

第 1 峑 標本ノ作製 1 . 固定法 2. 染色法

第 2 筫驗例

第 1 項 幼若舞踏鼠中樞神經/組織學的所見

第 1 項ノ概括
次

第 2 項 成熟舞踏鼠中樞神經, 組織學的所見 第 2 項 概括

第3章 綜 括

第 4 章 結 論

文獻，附圖，歐文抄銭

\section{緒嗆}

余ハ鼌二舞踏鼠ノ固有ナル廻旋運動ガ迷路機能ノ不完全ニ基ク 證明シ 次デ迷路ノ組織學的檢索 間迷路 正常二發有シ成長ト共二退行性變化 鼠/迷路機能不全入已二生後值二存スルモノニシテ加フルニ合其蝸牛迷路 ノ變性ハ甚ダ顯著ニシテ漸次進行性二㙕强スルト雖モ前庭性迷路ノ變性入 蝸牛迷路二比スレバ甚シク輕度ナルヨ知りタリ。

從テ舞踏鼠ノ生後直二存スル身體均衡障碍入單ニ末梢器ナル迷路ノ組織 學的檢索ノミア以ラハ未ダ說明スル能ハザルヨ知ルニ至レリ。

茲二本實驗二於テハ舞踏鼠ノ中樞神經殊二其聽神經中樞＝於ケル組織學

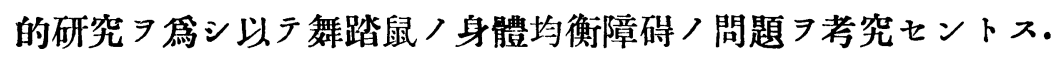

文献 ケル諸核ニ變化 認メズト云ヒ，Kuiper (1913)八舞踏鼠聽中樞ノ各部郎蝸 牛殼神經根繊維ノ退行變性, 腹核, 聽結節及菱形體等ノ織維ノ變性及其節 細胞ノ萎縮减少，前庭神經根纖維ノ變性及ダイテル氏核ノ縮少及减少习證 明シ，倘其上行性諸中樞ニモ輕度ノ退行性變化 $尹$ 認メ。且其前庭神經中樞

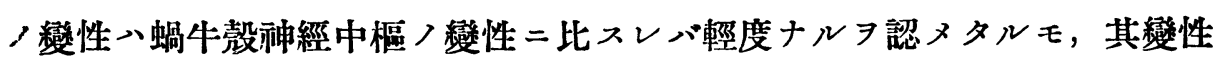
ガ末梢性ノモノナルヤヌ小中樞性ノモノナルャハ知ルラ得ズト云フ。 


\section{1. 固定法}

生體固定液トシテハWittmaack 氏液ノ醋酸习除外シタルモノ ス八吉井 Siebenmann 氏液 7 用フ。

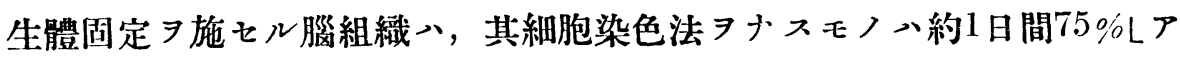
ルュールフ液二入レタル後 約 4 日間 $95 \%$ Lアルコールフ夜中二於テ固定シ，

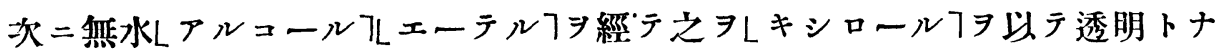
シしパラフィンフ包埋法习行フ・レマルキー7氏法ヨ施スモノ、約 1 迵間之ヨ Müller 氏固定液中二置キタル後次ノ液二入ル。

$$
\left.\begin{array}{cc}
1 \% \text { オオスミウム酸溶液 } & 1 \\
\text { Müller 氏液 } & 2
\end{array}\right\} \text {, 刋合 }
$$

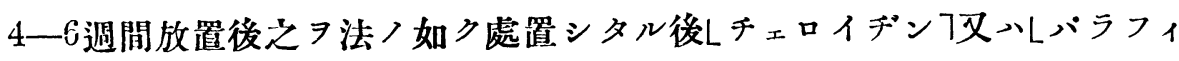
ン门包埋法ヨナス.

神經纖維染色法 $ᄏ$ 施スモノ八㨁二之ヨ miller 氏液中ニ容レ約 1 ケ月以 上固定シタル後法ノ如クレチェロイデンา包埋ヨ行フ・レチェロイヂンフ包埋組 織ハ10-18Lミクロンา, Lバラフィンา包埋組織ハ6-10Lミクロンフノ連續 切片トカス。

\section{2. 染色法}

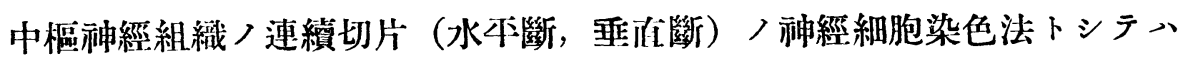
しアイビンへマトキシリン染色法, ニッスル氏Lトルイデンブラウ染色法 沃度Lメチレンブラウ染色法等习行と, 神經織維ノ染色法トシランLワイ グルトパール低染色法, クルチッキーベルテル氏染色法,ストレーべ氏染 色法，マルキー氏法，グリア細胞染色法及マロリ一氏染色法等习行フ。

\section{第 2 章 實 驗 例}

\section{第 1 項 幼若舞踏鼠ノ中樞神經ノ組織學的所見}

細胞染色法 1 號 8.0g. 平. 2 號 6.5g. 占. 3 號 4.6g. 占.

神經纎維染色法 1 號 $8.0 \mathrm{~g}$. 占. 2 號 $6.0 \mathrm{~g}$. 政. 3 號 4.5g. + +

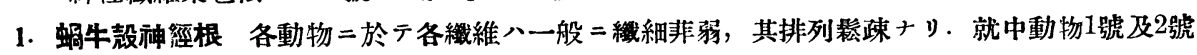
ニ於テハ輕度ナレド其染色不良ニシテ各織維二大小不同アリ,或八膨大絞㨦スルモノ或八萎縮シテ 細カク揄轉七ル細繩狀 呈スルモノアルヨ見ル.

2. 前庭神經根 其根織維八各動物 $=$ 一般 $=$ 正常 $L$ マス $7=$ 比シ細ク各瀻維八緎細菲弱其形態

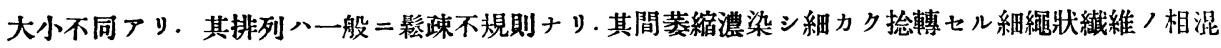

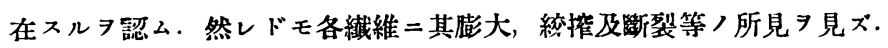


3. 腹桡及聽結節 腹核内ノ神經節細胞八散在性二䯿疎トナリ其數 サ正常鼠二比シ小ニシテ且大小不同アリ。シツスル氏小體ニ乏シク核ノ萎縮スルモ/相混在ス。正 常鼠/内腹側部二於テハ細胞最モ大ニシテ發育艮好ナルモ/密集スルモ舞踏鼠ニ於テハ其大イサ

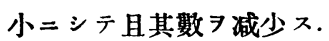

腹核尾端部二於ヶル細胞八正常鼠二形態小シニテ同大ナル細胞密集スレド, 舞踏鼠二於テハ其數 减少シ且其大イサ小

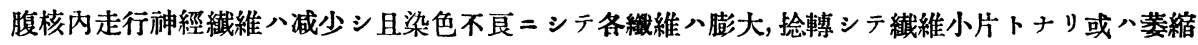

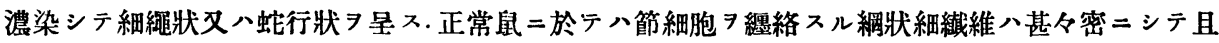
規則正シク經過 ス.

聽䊅節．顆粒層內ノ大尖形細胞八其大イサ小ニシテ或八菱縮濃染シ其散在甚シク稀少ナリ・大細 胞層中二於ヶル各種節細胞八其數 减少シテ排列䇗柾トナリ大サ小ニシテ且大小不同アリ，Lダリ

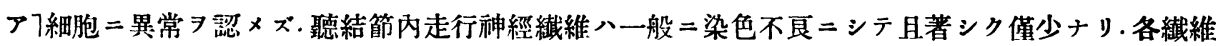

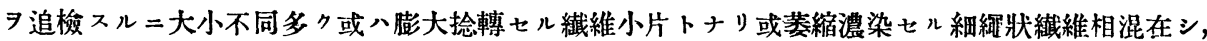

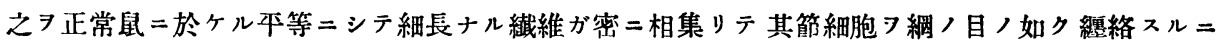

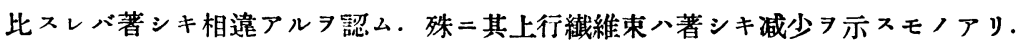

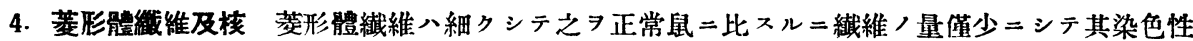
不良ナリ. 繊維間二八萎縮細繩狀 於テ八輕度ナルモ繊維/膨大，断裂及絞擭/變化 7 見ル。

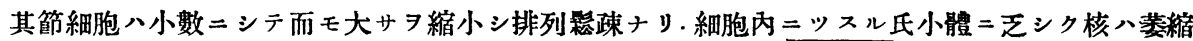
浱染スルモノアリ。

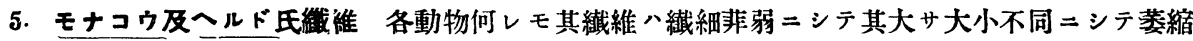

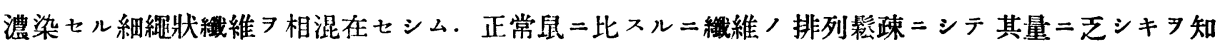
ル. 就中ヘルト氏繊維著シク减少シ且萎縮細悢狀习呈スルモノ多シ.

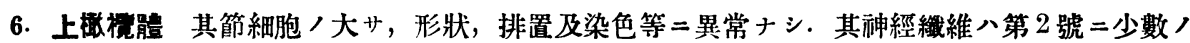
織維二萎縮濃染シ細繩狀

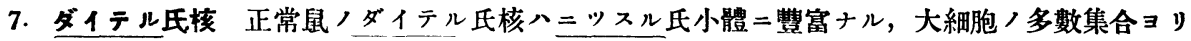

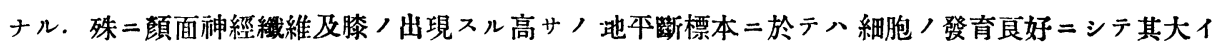
サ二不同尠ク本均直徑 $0.00286 \times 9$ 万至 $8 \mathrm{~cm} / モ$ 最モ多數 7 占 $\times$, 之 $\ni$ 內腹側群及外背側群 $=$ 區別 シ得. 舞踏鼠二於テハ一般二各號共其細胞ハ大小不同ニシテ發育不良ナル小細胞多ク 且一般二其 細胞數 $\exists$ 减 ジ平均直徑 $0.00286 \times 8 \mathrm{~cm}$ 以上八大細胞八甚々僅少ナリ.

就中內腹側細胞群二此變性顯著ニシテ外背側細胞群ニ於テ八其變性比較的輕度ナリ。

顏面神經繊維出現/前後二於テ該節細胞, 存在八正常鼠二比シ著明二减少シ 且其存在スル 細胞 八其大イサ小ニシテ不同アリ.

上述ノ所見ハ幼若舞踏鼠各號 $=$ 於テ何レモ同樣ニシテ其間大差ナシ. 唯 1 號ニ於テ該節細胞中ニ 散在性二菱緶浀染シ核ノ無構造ナルモノ少數习混在ス。

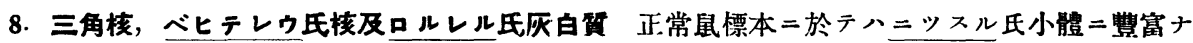
几細胞多數密集シ其大イサニ大小/不同尠ク其染色性良好ナリ.

舞踏鼠二於テハ三ツスル氏小體二そシク細胞/數ヨ减ジ且其大サ一般ニ小ニシテ加フルニ大小 ノ不同著明ナリ。從テ其排列八正常標本二比シ籍疎トナル。

9. 外側䠑係 外側蹄係ヨナス神經織維ノ形態，發育，染色等二異常ナク，其節細胞モ亦正常二 シテ異常ナシ. 


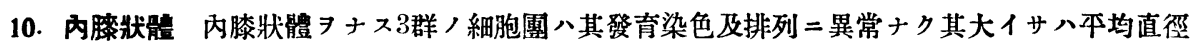
$0.00286 \times 4 \mathrm{~cm}$ 7算シ大小不同ナキコト正常鼠二於ケルガ如ン.

其內 7 走行スル神經緎維二異常 7 見ズ.

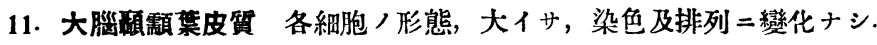

12. 小腹諸楼 N. Dentatus, N. globosus, N. Fastigii 及 N. embliformis 等其染色何レモ艮 好ニシテ其形態及排列正常ナリ.

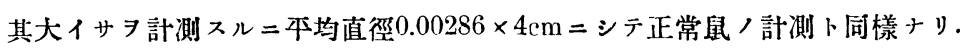

13. 小胋プルキンエ氏細胞 其排列, 形態及染色二異常ナク其大イサハ平均直徑 $0.00286 \times 5 \mathrm{~cm}$ э算ス.

14. 赤椄 其細胞ノ發育艮好 $=$ シテ形態, 排列及染色二變化ナク本均直徑 $0.00286 \times 7 \mathrm{~cm}$ 算シ 正常動物卜同樣+リ.

15. 䫀面神經及三叉神經 纖維/染色八良好ニシテ其形熊及排列二異常ナク, 其節細胞八本均直 徑 $0.00286 \times 7 \mathrm{~cm}=$ シテ正常鼠二於ケルト差異ヨ有セズ.

\section{本 項 概 括}

幼若舞踏鼠中楅ノ所見 $习$ 概括スル二各憸索動物二於テ其變化ノ顯藷ナル 八蝸牛殼神經根纖維, 前庭神經根纖維, 腹核及聽結節, 菱形體纖維及核並 ニダイテル氏核領域ニシテ其他ノ諸部二於テハ認ムべキ著變ヨ證セズ.

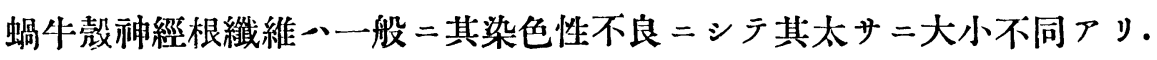
各纖維ハ纖細韭弱ニシテ處々二退行變性ニ非ザル萎縮濃染細繩狀ヨ呈スル 纖維相混在セシム．篇二其排列影柾ニシテ正常鼠ノ所見二比シ粗密ノ差著 シ.

纖維ノ膨大, 絞控, 斷裂及捻轉等ノ退行變性入 1 號二於テ輕度二之ヨ認 メ其他ノ動物二於テ認メズ.

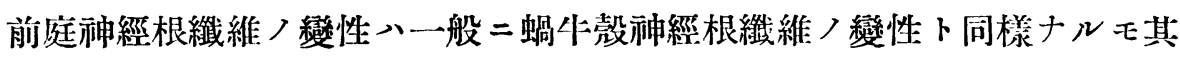
程度輕少ナリ。

腹核, 聽結節及菱形體二於ケル節細胞、一般二其形態小ニシテ發有幼若 ニシテ且大小ノ不同ヨ示シ其數モ亦顯著ニ少ナク笮疎ナル排列 示ス. 細 胞內ニッスル氏顆粒ニそシク萎縮濃染七ル核ヨ有スル細胞可點々散見スル モノアリ・其纖維八染色性不良ニシテ其量减少シ其大イ少不同アリ，且萎 縮濃染シ細繩狀ヨ呈スルモノ或ハ纖維小片トナり捻轉スルモノ等アリ。殊 二正常鼠ノ腹㤥及珀結節二於テ入其纖維入强勒細長ニシテ密二各節細胞 䌅絡シ網狀ヨナスト踓モ, 舞踏鼠二於テハ纖維粗ニシテ著シク减少シ若ク ハ消失々ルモノアリ。 
ヘ・ルド及モナコウ氏纖維入顯著二减少シ箖柾トナリ內二萎縮濃染シ細カ ク捻轉セル細繩狀纖維 $\ni$ 混在ス。

ダイテル氏核ハ一般二細胞數 ルコト稀少ニシテ疎トナリ各細胞二大小不同アリ，特二其內腹側群二於テ 然リトス。

其他三角核，ベヒテレウ氏核，ロルレル氏核ニ於テモダイテル氏核同樣 ノ所見 $习$ 存ス.

上述ノ如ク幼若舞踏鼠ノ第八對神經中榀部二於ヶル變化》其節細胞二退 行性變化ノ所見師ニッスル氏小體ノ消失，胞體內空泡ノ形成，胞體ノ膨大 乃至 $L$ ノロファギーフ等ノ變化ヨ認ムルコトナク，一般ニ細胞ノ發育不全 ヨ示ス，又神經纖維二於ヶル所見ハ發育不全 $ヨ$ 主トシ退行變性ハ時二輕微 ニ之ヨ證スルノミ。

\section{第 2 項 成熟舞踏鼠中樞神經ノ組織學的所見}

細胞染色法 1 號 13.8g. 占. 2 號 13.5g. 占. 3 號 12.5g. \&. 4 號 11.5g. \&. 神經緎維染色法 1 號 13.5g. 占. 2 號 13.0g. 占. 3 號 12 8g. 占. 4 號 11.0g. 占.

1. 䗁牛款神陘根 全例二於テ其織維八减少シ, 各織維八一般二織細菲溥ニシテ且大小不同多ク

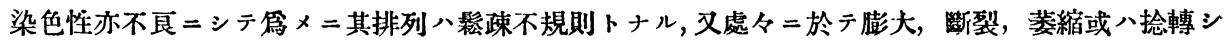
テ蛇行狀 7 呈ス儿瀻維 7 混在ス。

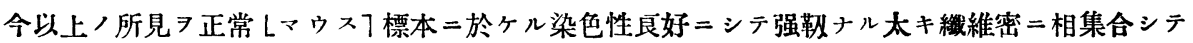
走行スルニ比スレバ影著ノ相違アルヨ知ル。

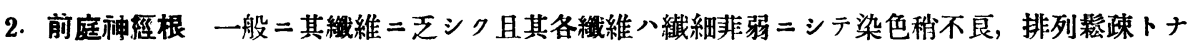

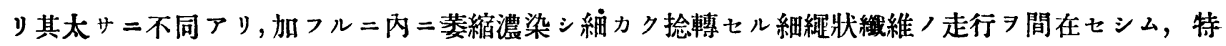
$=1$ 號及 2 號二於テ八緎維, 膨大, 断裂, 捻轉等 $\exists$ 稍著明二認么.

前庭神經根二於ケル變化八蝸牛殼神䋑根/變化二比スルニ爾ク顯著ナラズ.

3. 腹栚及㯖結節 腹核内神經節細胞ハ各號ニ於テ正常鼠二比スレバ甚シク其數ニそシク細胞小 ナルモノ多ク大細胞八甚ダ僅少ナリ，而モ小細胞各個八互二大小不同アリ.正常鼠二於テ八本均直 徑 $0.00286 \times 7$ 乃至 $6 \mathrm{~cm} /$ 細胞多數相密集スルモ，舞踏鼠二於テ八本均直徑 $0.00286 \times 3$ 乃至 $4 \mathrm{~cm}$ ，

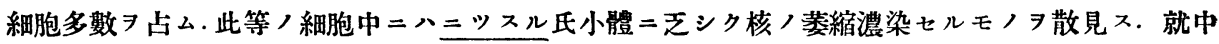
腹核ノ內腹側部 ニ於テハ細胞數僅少ニシテ小細胞ノミ鬆柾ニ在スルヨ認ム。此部八正常鼠二於テ八 最モ發育艮好ナル大細胞ノ多數密集スル部ナリ

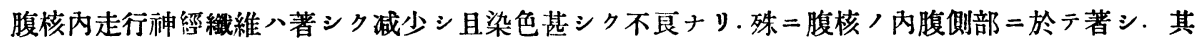

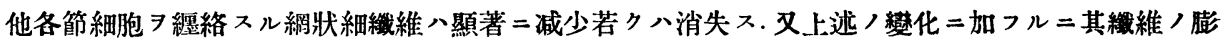

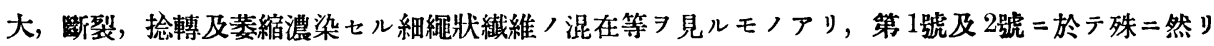
トス.

聽結節內神經節細胞八一般二其數减少シ 且各細胞八小ニシテ大小不同アリ，顆粒層中ノ大尖形

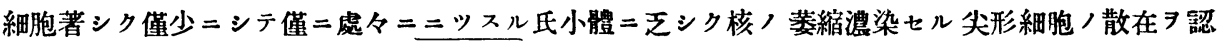


ムルニ過ギザルモノ多シ. ・

又大細胞㒶中 =於テ細胞數著シク减少シ其配置疎トナリ其間萎縮濃染セル細胞

其他グッア細胞二異常ナシ. 以上ハ正常鼠ノニッスル氏小體二蔧富ナル大尖形細胞ノ多數 スル顆粒層及正常ノ形態 層等二比較スル時八顯著ノ相違

聽結節內走行神經織維八一般二其量僅少且染色不良ニシテ合瀻維 $/$ 膨大, 斷裂, 捻轉或八萎縮濃 染シ細カク捻轉走行スル細繩狀緎維等アリテ其排列不規則ナリ 此部ョリ上行シテ所謂聽線トナ ル可キ纖維八極メテ僅少ニシテ且太細不同多ク排列亦踈ニシテ其間萎縮濃染セル綇維

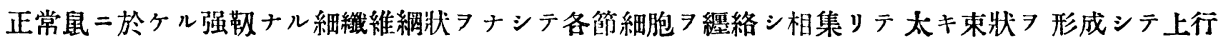
スルニ比スレバ著明ノ相違习認容セシム。

上述ノ腹核及聽結節ノ變性ハ各動物ニ殆ンド同樣ナリト踓モ特二第 1 號及第 2 號二顯著ナリ.

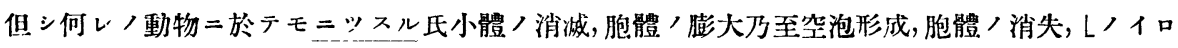

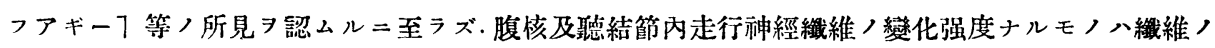

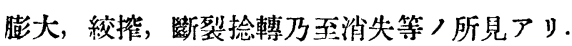

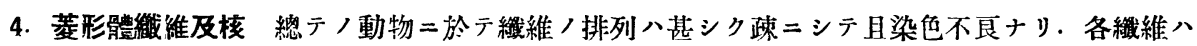

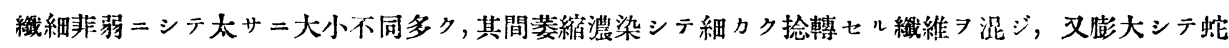

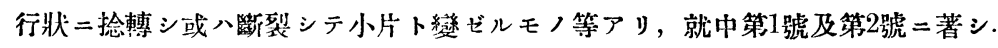

蓺形體內節細胞八正常鼠二比シ僅少ニシテ且其大イサ小ニシテ加フルニ大小ノ不同アリテ排列

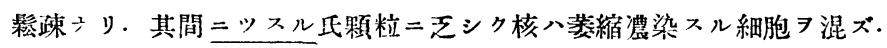

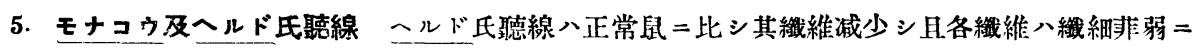

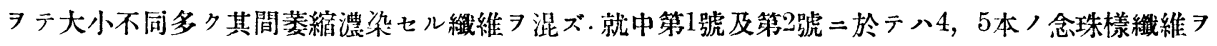
遺殘スルノミ。

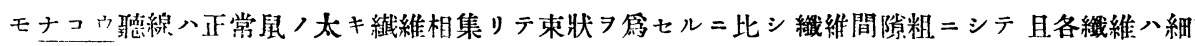
ク棐弱ニシテ，膨大捻轉シ又、菱維シ念珠狀トナレルモノ 戀化著シ.

6. 上橄熘體 一般二其神經織維二著變ナシ.

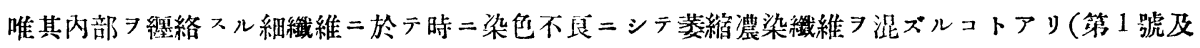
第2 號)

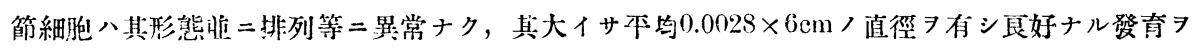
示ス.

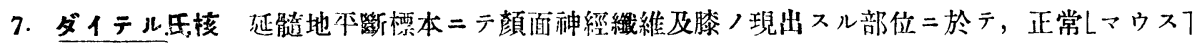

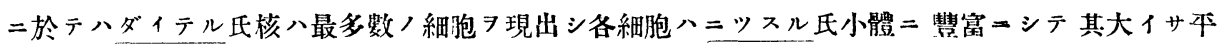
均直徑 $0.00286<9$ 乃至 $10 \mathrm{~cm}$ 算スル大尖形細胞ョリ第リ大小不同勘》且其細片群八內腹側群及外 背勋群二大则シ得

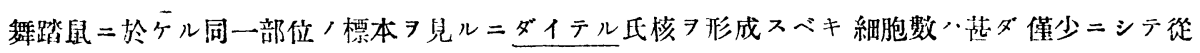

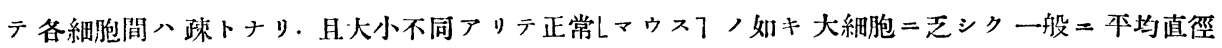
$000286 \times 5$ 万至 $6 \mathrm{~cm}$ ノ小細胞 $尹$ 最多トス. 其細胞ニシツスル氏顆粒乏シク核八萎縮濃染七ルモノ 泚在ス. 就中内腹侧群二於テハ細胞/减少著シク, 存在七ル細胞八短小ニシテ加フルニ大小不揃ナ

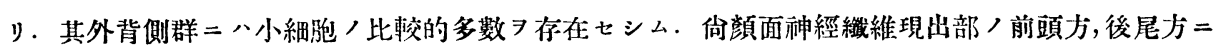
於テダ・テル氏核細胞八漸次减少スルモ少發育良好ナル神經細胞ヨ多數出現スルヨ正常トスルモ,

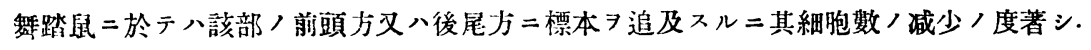


要之ダイテル氏核二於テ神經細胞數ノ少ナキコト，大イサノ小ナルコト及存在セル細胞二大小 不同ノ顯著ナル等 7 認么.

然レドモニッスル氏小體/消减, 胞體及㤥ノ膨大, 空泡/形成, ᄂノイロフアギー等ノ所見八何レ 八例二於テモ之ヨ缺ク。

8. 三角核，ベヒテレウ氏核及ロルレル氏灰白質 正常鼠標本卜對比シテ檢スル＝舞踏鼠標本二

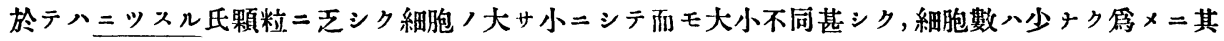
排列正常 ノ如ク密在セズシテ疎ナリ.

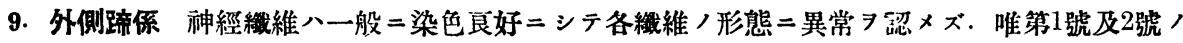
標本二萎縮澧染シテ細カク捻轉セル蟣維ノ混ズルモノアリ。

神經細胞ノ形態前二染色二貿継ナシ。

10. 內珤狀體 各細胞群二於ヶル神經細胞 / 形狀, 染色, 分布狀態二異常ナク 其大イサ平均直

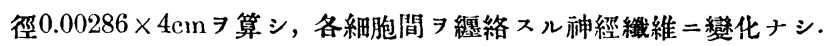

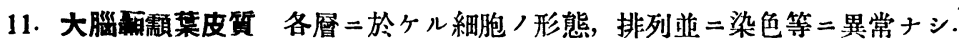

12. 小巡諸校 N. dentatus, N. globosus, N. fastigii 及 $\mathrm{N}$. emboliformis 等二於ヶル各細胞 八發育宸好ニシテ其形態, 染色及排列等何レモ正常 Lマウスフト同樣ニシテ細胞ノ大イサ本均直徑 $0.00286 \times 4 \mathrm{~cm}$ ヨ占ムルモ/最多數=シテえレ亦正常鼠二近似ス.

13. 小腦プルキンエ氏鳎胞 其排列, 染色及形態二異常ナク退行数性ノ證スベキモノナク其大イ サ平均直徑 $0.00286 \times 6 \mathrm{~cm}$ 习示シ正常鼠二於ケルト同樣/破育习示ス.

14. 赤䊁 形態, 染色及排列二變化ナク平均直徑 $0.00286 \times 6 \mathrm{~cm} /$ 大イサシ示シ 正常瓦ト差違ナ キヨ示ス.

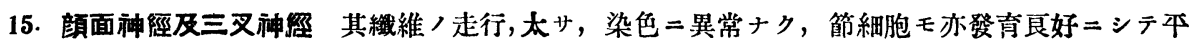
均直徑 $0.00286 \times 7 \mathrm{~cm}$ ノ大サ $コ$ 示スコト正常鼠ノ如ク其他微細構造二病異

\section{本 項 概 括}

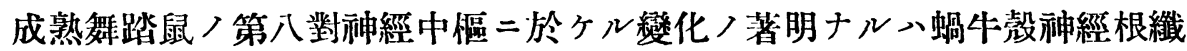
維，腹核及聽祮節，荾形體纖維及核，ダイテル氏核領域及前庭神經根纖維 等ニアリ・

蝸作殼神經根纖維入减少シ染色不良，纖維ノ太細不同，排列ノ柾，各纖 維》纖細韭弱ニシテ萎絔濃染シ細カク捻轉七ル纖維

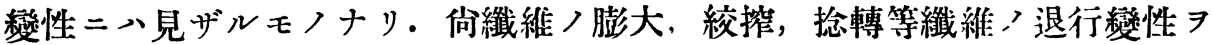
モ稍著明ニ之ヨ認ムルモノアリ・腹核及聽結節ノ神經細胞、第 1 號及 2 號 二顯著ナルモ其他ノ例ニアリテモ正常鼠二比スル時ハ其變化

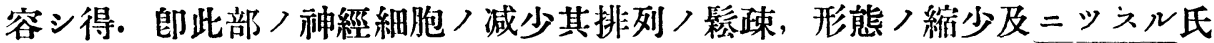
顆粒ニそシク核つ萎縮濃染七ル細胞ヨ其間二混在七シム。腹核ノ特二其內 腹側部二於テ細胞ノ减少著シ。聽結節ノ顆粒層中ノ大尖形細胞及大細胞層 中ノ各神經細胞入其數 $\ni$ 减ジイサ小ナリ. 
腹核及聽結節內走行神經纖維 モ顯著二减少シ，各纎維二膨大，絞控，斷 裂及捻轉 7 見又纖維小片ト變ジ樹枝狀 $\ni$ 呈シ其間萎縮濃染細カク捻轉七 ル纖維ヨ混汭染色不良ナリ。倘各節細胞 殆ンド消滅スルモノアリ。

上記腹核及聽結節ノ變化、各動物ニ同樣ナレドモ第 3 及第 4 號二於テ稍 輕微ナリ.

モナンウ及へルド氏聽線二於テモ其纖維二已述ノ他ノ纖維同荄ノ戀化厂 リ・菱形體ニ於テモ節細胞及纖維二已記他神經細胞及纖維卜同樣ノ變化ノ y.

前庭神經根入纖維ノ减少，排列ノ娤踈，太サノ不同等アリ，又萎縮濃染

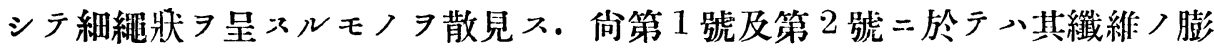

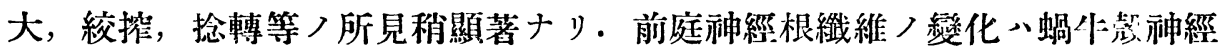
根纖維ノ夫レニ比スレバ一般二輕度ナルハ泩意スベシ。

ダイテル氏核領域二於テ入其節細胞ノ减少，大細胞ノ僅少ニシテ小細胞 ノ多數ナルコト及小細胞モ互二大サノ不同著シ. 殊二其顏面种經纖維現出 部二於テ其內腹側部二位スル該節細胞ノ减少乃至大イサノ小ナルコトハ顯 著ナリ。

上橄欖體，外側蹄係等ノ神經纖維入第 1 號及第 2 號二於テ少數二其纖維 ノ萎縮嶩染シテ細カク捻轉スルモノアレド其他ノ各號ハ殆ンド買常ヨ認メ

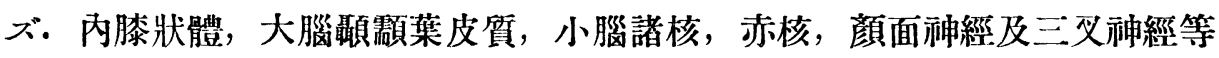
二異常ヨ認メズ.

已記諸中橿部二於ケル神經節細胞ノ變化二胞體ノ膨大，ニッスル氏小體 ノ消失, 核つ膨大及萎縮, 胞體內空泡ノ形成及ビしノイロファギーフノ狀態等

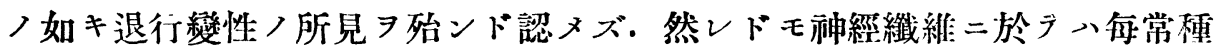
ケノ程度二於ケル退行性變化ヨ認メタリ・少又已記ノ諸變化ハ左不兩側二 變化ノ差異ノ著シキモノナシ。

\section{第3童 綻括}

幼若舞踏鼠及成熟舞踏鼠ノ中橾神經殊二第八對神經中榀二於ヶル所見

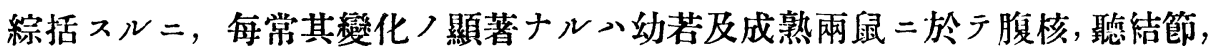
菱形體，ダイテル氏核領域，螖作殼神經根纖維及前庭神經根纖維等ノ部二 
在り・蝸牛殼神經根纖維入幼若及成熟舞踏鼠二其纖維ノ纖細非弱ニシテ明 カ二其减少 $\ni$ 見, 纖維ノ太サ

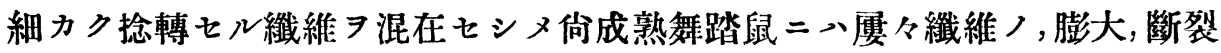
絞㩁, 捻轉等 7 見出ス.

前庭神經根纖維二於テモ均シク幼若及成熟兩鼠二颱牛殼神經纖維 $/$ 變化 ト相似タル變化 見ルト雖モ一般ニえレニ比シテ輕度ナルノ相違ヨ認ム。

腹核及聽結節二於テハ幼若及成熟兩鼠ノ節細胞二數ノ减少，倭小ナル形 態, 細胞ノ大イサノ不同及排列ノ柾ニシテ，殊二腹核內腹側群ノ細胞入正 常鼠二八多數密集シ其大イサ本均 $0.00286 \times 5$ 乃至 $6 \mathrm{~cm}$ 直徑 有スレド, 舞踏鼠二於テ 過ギザルモノ多シ'・更二成熟舞踏鼠二於シハ其間濃染萎縮セル細胞习散在

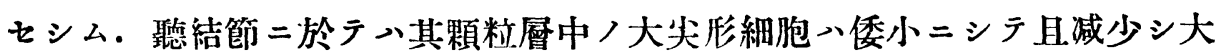
細胞層中ノ各種節細胞ノ减少, 其大イサノイナルコト, 排列柾ニシテ點々萎

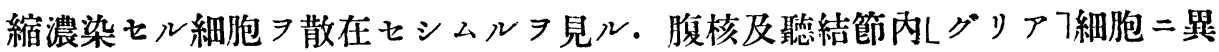
常ナシ.

腹核及聽結節內神經纖維入幼若及成熟兩舞踏鼠二於テ正常鼠二比シ甚シ ク减少シ, 染色不良ニシテ其排列不規則且鬆疎ナリ. 各節細胞 $习$ 緟絡スル 網狀細纖維入著シキ减少乃至消失 $ヨ$ 見ル。就中成熟舞踏鼠二於テ 、纎維ノ 膨大，斷裂，絞推，捻轉或一萎縮濃染シ細カク捻轉セル細繩狀等ノ所見 呈スルモノアリ・正常鼠ノ對照標本二於テハ斯ノ如キ所見ナシ.

苾形體纖維入幼若及成熟兩舞踏鼠二纖維ノ减少，排列ノ不規則鬆疎，其 太サノ大小不同及萎縮濃染シ細カク捻轉セル纖維ノ混在等 7 認メ, 仯成熟 舞踏鼠二於テハ之二加フルニ纖維ノ膨大, 絞控, 捻轉等ノ所見 $コ$ 呈スルモ ノアリ。蔆形體㤥、細胞ノ减少，其形態ノ縮少，大イサノ不同等アリテ其 間濃染萎縮セル細胞ヨ散見ス。

ダイテッ氏核ハ幼若及成熱兩舞踏鼠二細胞ノ减少顯著ニシテ各細胞入發 育不良倭小ニシテ而そ大小ノ不同多ク大細胞い極メテ稀レニ之ヨ認ムルノ ミ，顏面种經纖維及㯟ノ現出スル部位二於ケル對照正常鼠地本断標本ニテ 、節細胞本均调徑 $0.00286 \times 10$ 万至 $9 \mathrm{~cm}$ ナルニ比シ舞踏鼠ノ該細胞い著シク 小ナリ，ダイテル氏核ノ内腹側群二於テハ上記ノ變化特二顯著ナリ. 
其他三角核，ペヒテレウ氏核，ロルレル氏灰白質等二細胞ノ减少，形態 ノ縮少，大イサノ不同及其排列鬆柾等 幼若及成熟兩鼠二纖維ノ减少, 各纖維ノ太細不同, 走行ノ牃柾及萎縮濃染 シ細カク捻轉セル細繩狀纖維ノ混在 $ヨ$ 見ル。殊ニへルド氏纖維ノ减少八顯 著ナリトス。

上橄欖體二メ其細胞及纖維二買常ヨ認メザルモ成熟舞踏鼠二於テハ少許 濃染萎縮セル纖維ノ混在スルコトアリ。

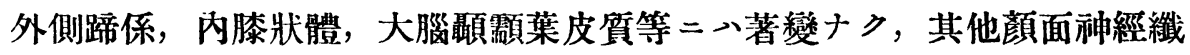
維及核，三文神經纎維及核，赤核，小腦內諸核郎 N. deutatus, N. globosus, N. fastigii 及 $\mathrm{N}$. emboliformis 並二小腦プルキンエ氏細胞等二病變 ズ.

上來記述ノ如ク幼若及成熟舞踏鼠第八對神經中榀ノ所見 八大略同樣ニシ テ，神經細胞ノ减少, 細胞ノ倭小二シテ而モ大小ノ不同 氏小體ノ消失，胞體內空泡ノ形成及Lノイロファギーフ等ノ如キ戀性ヨ殆ン ト見ズ.

神經纖維ニ於テモ纖維ノ减少，各纖維ノ纖細菲弱ナルコト，其太サニ大 小不揃ノ著シキコト，排列ノ柾ナルコト並二網狀細纎維ノ减少乃至消失等 ヨ主要ナル所見トシ，成熟舞踏鼠二メ之二纖維ノ膨大，絞按，捻轉，断裂 等ノ退行變性ノ所見 $\ni$ 加フ. 從テ舞踏鼠第八對神經中樞ニ於ヶル變化ハ一 般二神經細胞及纖維ノ發育不全 所見 成熟舞踏鼠二稍々顯著二之ヨ認么ルモ幼若舞踏鼠二八甚ダ輕度二之 ヨ證スルノミ・而シテ其變性ノ最モ顯著ナルい第一終止核師腹核，聽結節 並ニダイテル氏核領域ニシテ菱形體之二次ギ, 上橄㰖體, 外側蹄係, 內膝 狀體及大腦影䫫葉皮質等〉上位中樞二ハ極メテ輕度ナル變化ヨ證スルカ乃 至小全ク變化ヨ認メズ. Kuiper ハ已述ノ如ク舞踏鼠聽神經中樞領域二退 行變性 7 認メタリト踓モ, 余ノ研究二從七幼若並二成熟舞踏鼠 $\exists$ 正常鼠卜 彼我相對照シテ檢索セル結果ヨリ観ル時ハ舞踏鼠二於ケル第八對种經中樞 領域ノ變化い之ヨ其發育不全ト認ムルタ至當ト七ン,

余ガ多年二亘りテ觀察七ル舞踏鼠ノ生理的研究並二末梢二於ヶル咏器迷

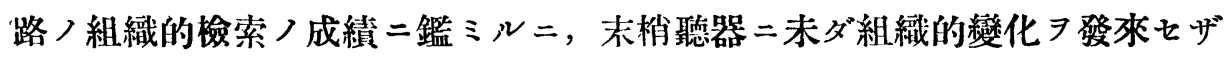


ル以前ニ於テ已二迷路性諸機能ニ一定ノ障碍 中樞ニ於ヶル發有不全二其因ヨ歸スベク，生後一定時期 ヨ待テテ初メテ發 育不完全ニシテ其抵抗微弱ナル中樞領域二輕度ノ退行變性 樞二於ヶル發有不全亚二退行變性入延七テ末梢聽器迷路二二次的退行變性 ヨ繼發七ルモノト說明スルョ以テ妥當ナリトセン。

\section{第 4 章 結踚}

1. 幼若並成熟舞踏鼠第入對神經中樞二組織的變化 7 認么。其最モ顯著 ナルハ第八對神經中樞ノ腹核，聽結節及ダイテル氏核領域ニシテ蝸牛殼神 經根纖維，菱形體纖維及核，モナコウ及ヘルド氏聽線，前庭神經根纖維等 ノ變化之二亞グ。

2. 上述諸部ニ於ヶル變化ハ神經細胞ノ著シキ减少，存在スル細胞ノ倭 小, 各細胞相互ノ大サニ不同著シキコト, 其細胞群配列ノ疎ナルコトラ以 テ主要ノ變化トシ, 神經纖維ニアリテメ均シク纖維ノ减少, 各緎維ノ極メ ラ纖細韭弱ニシテ且染色性ニそシキュト，形態ノ不同，其排列及走行ノ獎 踈ナルコト，一般二細小ナル纖維ナルニモ拘ラズ倘太細不同著シク㕍々中 二萎縮濃染シ細カク捻轉セル蟣維 $コ$ 混ズルコトアル等ヨ以ラ.主要ノ變化ト シ，更二成熟鼠二至レバ纖維ノ膨大，絞㩁，斷裂，捻轉等ノ退行變性ノ存 在スルラ認ム。

3. 幼若亚二成熟兩舞踏鼠ノ神經節細胞二於ヶル變化二八互二顯著ナル 差異ヨ認メザルモ，神經纖維ノ變化ニ於テハ兩鼠二已記ノ相違ヨ證ス。

4. 一般二螖牛殼神經中樞ノ變化入前庭神經中樞ノ夫レニ比シ强度ナリ。

5. 已記第八對神經諸中樞部位二於ヶル神經細胞ニハ著明ナル退行變性 フ殆ンド認メズト踓モ，其神經繊維ニ於テハ主トシテ成熟舞踏鼠二退行性 佥化习認么。

6. 上橄欖體及外側蹄係ニ於ケル纖維變化ハ少ナク,之レアル場合ニモ輕 度ニシテ，內膝狀體及大腦顳㛲葉皮質二八著變ナシ。

7. 舞踏鼠第八對神經中樞ニ於ヶル所見八該神經細咆及緎維ノ發育不全 ヨ主要ノ變化トシ，動物ノ成熟スルニ及ンデ稍顯著ナル退行變性ヨ認ム。

8. 舞踏鼠ノ聽器迷路ノ變性 (已報參照) 一第八對神經中榀領城ニ於ヶル

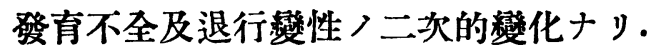




\section{Literatur.}

1) Alagna, Beiträge zur normalen und pathologischen Histologie der Ganglion des Akustikus. Arch. f. O. Bd. 82. S. 304.1910.

2) Alexander u. Obersteiner, Das Verhalten des normalen Nervus cochlearıs im Meatus auditorius internus. Zeit. f. O. Bd. 58. S. 221. 3) Alexander u. Marburg, Handbuch der Neurologie des Ohres. 4) Bielschowsky, Ủber spätinfantile familiäie amauiotische Idiotie mit Kleinhirnsymptomen. Deutsch. Zeitschrift. f. Neur. 1914. I. S. 7. j. f. Psych. u. Neur. 1921. XXVI. S. 123. Baginsky. Über die Verhalten von Neirenendorganen nach durchschneidung der zugehörigen Nerren. Virchow. Arch. Bd. 137. 1894.

6) Derselbe, Über den Ursprung und den centralen Verlauf des Nervus acustıcus des Kaninchens. Vuch. Arch. Bd. 105. S. 28. 1886. Bd. 119. S. $811890 . \quad 7)$ Bechterew, Zur Frage üher den Ursprung des Hörnerven und uber die physiologische Bedeutung d. N. vestrbularis. Neurol. Centralb. S. 191. 1887. 8) Brouwer B, Das Gehrn einer kongenital tauben Katze. Fol. neurobiol. 1912. VI. 197. 9) Brouwer u. Walree, Ueber den Hurnstamm enes Taubstummen. Fol. neurobiol. 1914. VIII. 589. 10) Brunner, Die centralen Kleinhirnkeine bei den Säugetieren. Ibidem $200 . \quad 11)$ Flechsig, Zur Lehre von zentralen Verlauf der Sinnesnerven. Neurol. Centralbl. S. 545. 1886. 12) Freud, Über den Ursprung des Nervus acusticus. M. f. O. j. g. 20. No. 8 -9. 1886 . 13) Forel, Vo:läufige Mittheilungen uber den Ursprung des Nervus acusticus. Neurol. Centialb. 1885. $1887 . \quad 14)$ Fuse, Innerer Aufbau der zentralen akustischen Bahnen. u. s. w. Arbeit aus dem Anatomischen Inst. d. kaiserl.-japan. Universt zu Sendai. Heft. II. 1919. 15) Held, Relträge zur feineren Anatomie des Kleinhirn und Hirnstammes. Arch. f. Anat. u. Physiolog, S. 435. $1893 . \quad$ 16) Derselbe, Die centralen Bahnen des Nervus acusticus bei der Katze. Arch. f. Anat. u. psych. 1891. 17) Kuiper T. Die funktionellen u. hrnanatomischen Befunde bei der japanischen 1 anzmaus. Rotterdam. $1913 . \quad$ 18) Knik, Pathologische Histologie des Ohrlabyrinth nach Durchschneıdung des Nervus acustıcus. Zeit. f. O. Bd. 65. S. 342. $1912 . \quad 19)$ Derselbe, Uber sekundäre regeneration im inneren Ohre nach Acusticusstammverletzungen. D. O. G. 1911. A. f. O. Bd. 88. S. 15. $1912 . \quad 20)$ Kappers, Vergleschende Anatomie d. Nervensystems. 1920. 1921. 21) Lewy, Degenerations versuche am akustischen System des Kaninchens und der Katze. Fol. neurol. 1909. Der Deiterssche Kern und das Deiterospinale Bundel. Monakow. Aib. 1910. IV. 229 . 22$)$ Monakow; Über den Ursprung und d. zentralen Verlauf des Acust.cus. Neurol. Centralb. S. 201. 1887. Onufrowiz, Experimenteller Beitrag zur Kenntniss des Ursprungs des N. acusticus des Kaninchens. Arch. f. Psych. Bd. XVI. $1885 . \quad 24)$ Quix u. Brouwer, Beitrag zur Anatomie der congenitalen Taubheit. Denkers Anatomie der Taubstummheit. Wiesbaden. 1910. 25) Ramony Cajal, Beitrag zum Studium der Medulla oblongata des Kleinhrrns u. s. w. $1896 . \quad 26)$ Schaffer, Weitere Beitrage zur pathologischen Histologie der familiären amaurotischen Idiote. j. f. psych. u. Neur. 1905. VI. S. $84 . \quad 27$ ) Winkler, Experimenteller Beitrag zur Kenntnis der sec. Hörbahn der Katze. Ib dem. 1911. V.

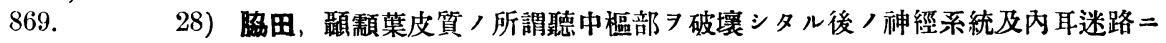
於ヶ儿賽驗的病理. 耳鼻咽喉科京都臨床 第14卷 第15卷. 29) 西田, 聽神經終末器官 卜同神經聽路卜/相對的及其續發的各變化/病理實驗 其一及其二. 耳鼻㸶喉科京都臨來 第 15 卷 第16忩.

\section{附 堛 說 明}

第 1 圖（ライツ接眼 3 -接物て）シツスル氏トトルイヂンブラウフ染色法 幼若舞踏鼠/腹核内神經節細胞/短小及排列/整疎 7 示

第2图（同上）同上染色法 幼若正常鼠 /腹核內神經節細胞 


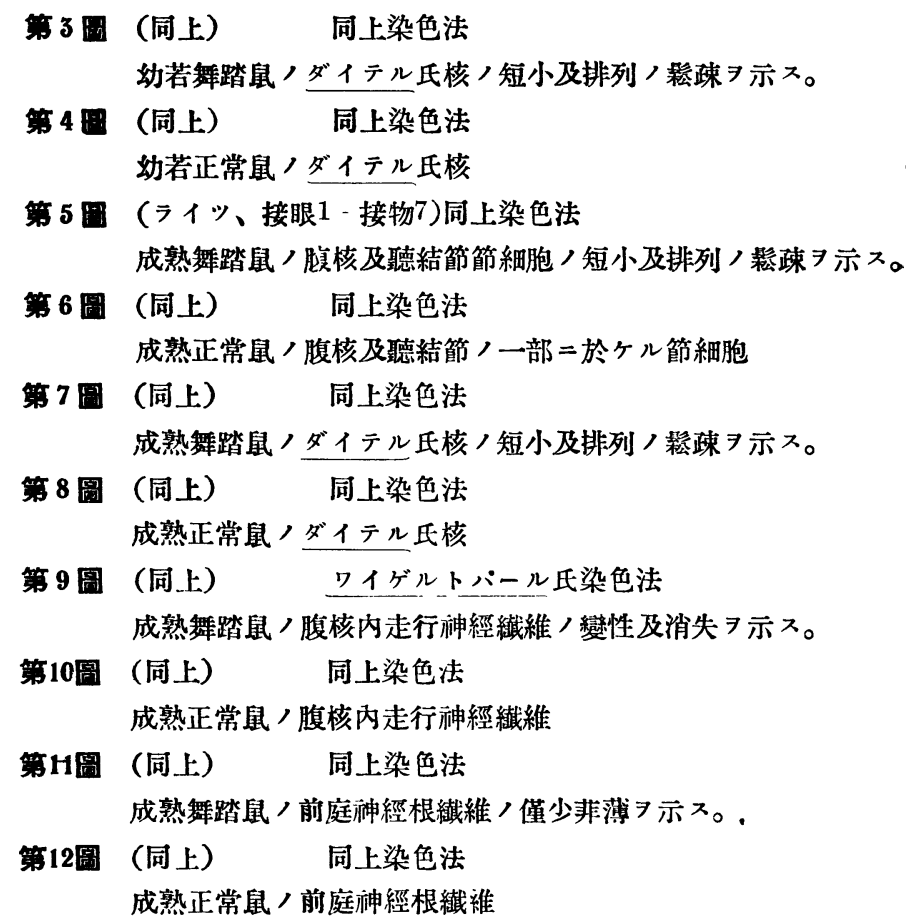

Kurze Inhaltsangabe.

\section{Histo-pathologische Untersuchungen der Octavuszentren der Tanzmaus.}

Von

T. Hattoni.

(Ans der oto-rhino-u. laryngologischen Klinik der kaiserlichen Universität zu Kyoto. Direktor: Prof. Dr. T. Hoshino.)

1) Wenn man die Veränderungen an den Octavuszentren junger und erwachsener Tanzmäuse histopathologische studiert, dann sind die hochgradigen Erscheinungen in Nucleus ventralis, Tuberculum acusticum und Nucleus deiters Gebiete in erster Linie zunennen. Dann folgen solche an Cochlearen Wurzeln, im Nucleus trapezoideus, an Monakow und Heldsche 
服 dóg 6og if at $96-d x+25 \%$

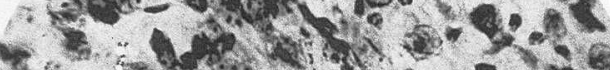
4.

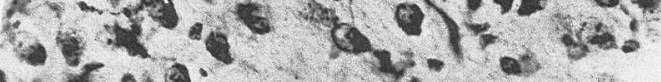

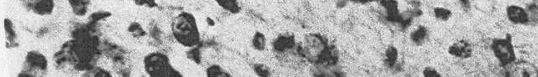

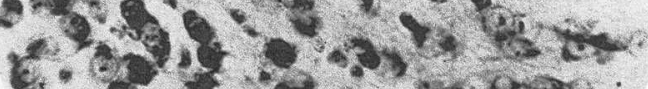

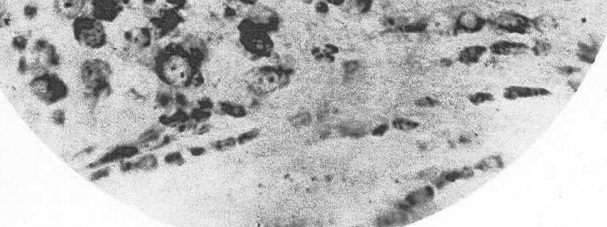

\section{第 3 圖}

\section{0,1800}

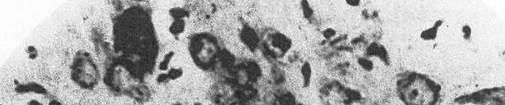

$\because 0.0-6$

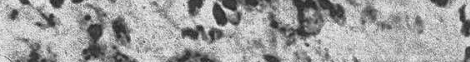

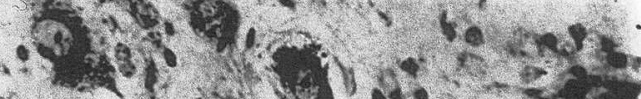

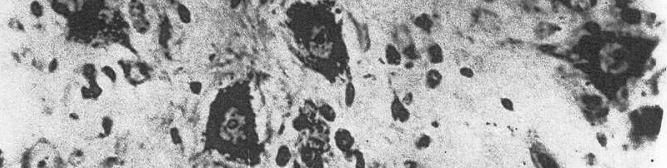

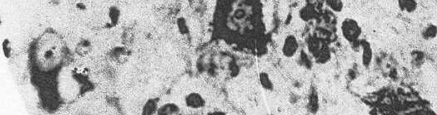

1s. 60 it

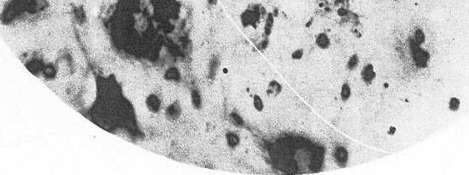

第 5 圖
96. +2

$2 \times 3$.

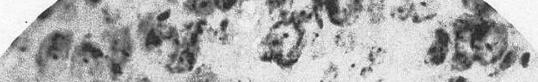

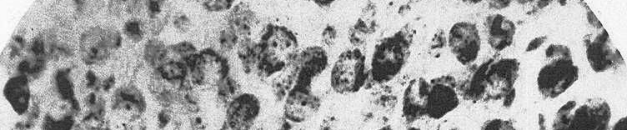

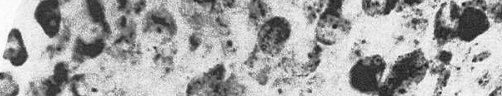

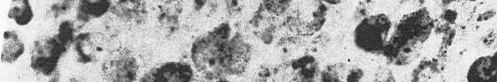

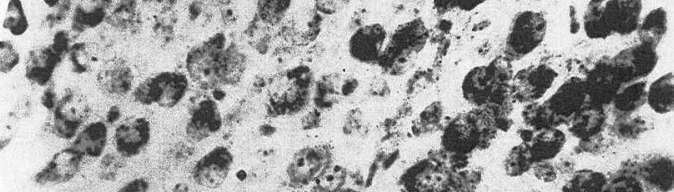

- 2. 0 on

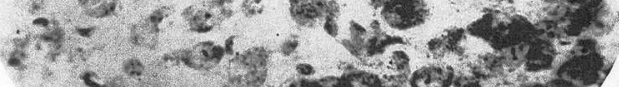

से

-

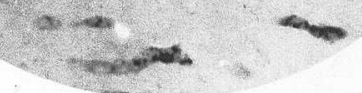

第 4 圖

$\ln _{3}$ ent?

4. 8 in

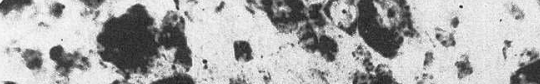

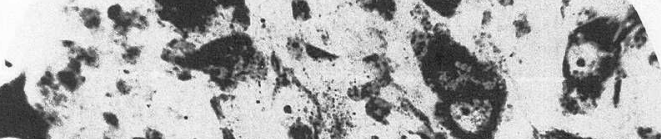

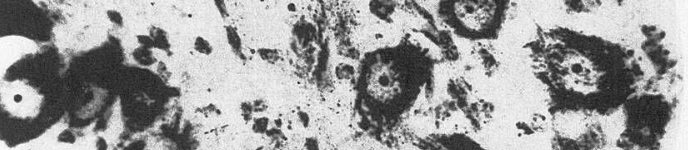

है.

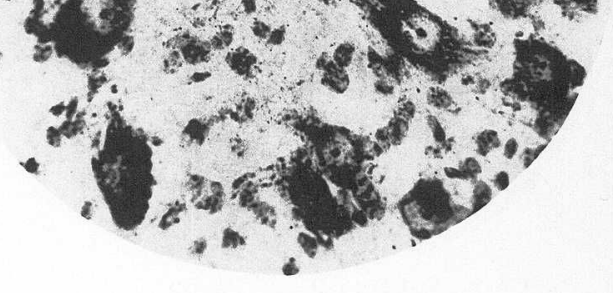

第 6 圖
部

部简

文

附

[밈
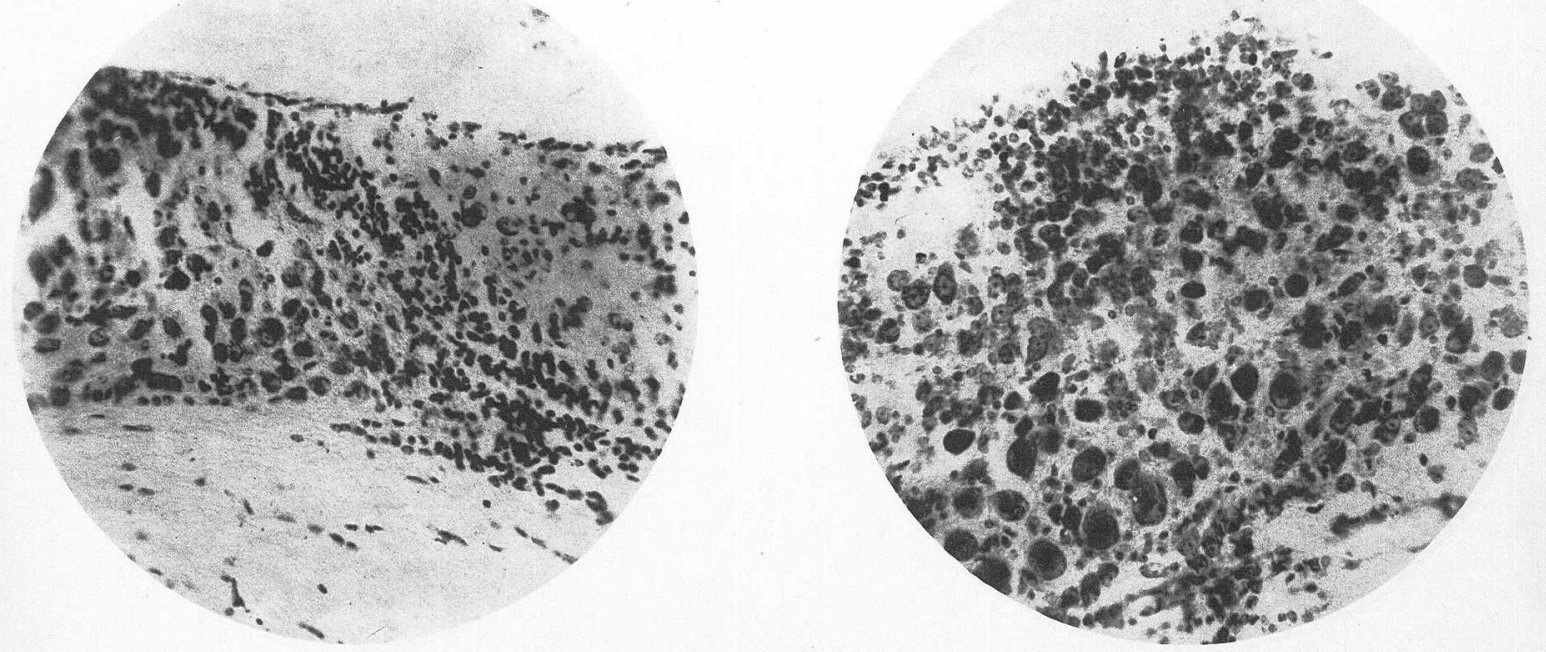
Fasern und den vestibulären Wurzeln.

2) Ganglionzellen sind im bemerkenwerter Weise verminclert und verkleinert. Die Grösse jeder Zelle ist unterschiedlich. Die Lockerung der Anordnung derselben springt in's Auge. Die Nervenfasern lassen eine deutliche Fasern-Verminderung erkennen. Jede einzelne Faser ist diunn und ihre Fahigkeit zum Farben wenig günstig. Die Form jeder einzelnen Faser ist verschieden und eine Lockerung der Anordnung vorhanden. Fasern, welche zu Atrophie neigen, übertälat sind und anstatt eines geraden Verlanfes einen Gewundenen haben, sind haufig zu finden. An erwachsenen Tanzmausen kann man Faseranschwellung, Einschnürrungen an denselben und einen gewundenen Verlauf derselben beobachten.

3) Die Ganglion Zellen junger und erwachsener Versuchstiere sind in ihren Veranderungen einander ziemlich ähnlich, aber die Nervenfasern weiseu die oben beschriebenen unterschiedlichen Erscheinungen auf.

4) Im Allgemeinen sind die Veranderungen an Cochlearen Zentren starker, als solche an Vestibularen Zentren.

5) Bemerkenswert ist, dass an den Erscheinungen der Octavuszentren Degenerationen der Ganglionzellen fast nicht auftreten, aber degenerative Veranderungen der Nervenfasern, hauptsachlich bei erwachsenen Tanzmäusen, sich bemerkbar machen.

6) Die Fasern der oberen Olive und Leminiscus lateralis sind leichten Grades verandert. Korpus quadrigeminum medium und Lobus temporalis machen fast einen normalen Eindruck.

7) Der allgemeine Befiund der Octavuszentren der Tanzniause ist hauptsachlich ein Entwickeluu,gsmangel der Ganglionzellen und Nervenfasern. Bei erwachsenen Tauzmausen treten ziemlich bedeutende degenerative Veranderungen in Augenschein

8) Die Veranderungen des Ohrlabyrinthes der Tanzmanse (sieh III. Mittheilg.) lassen vermuten, dass der Entwickelungsmangel und degenerative Atrophie der Octavuszentrengebietes das Auftreten sekunlare Degenerationen des Ohrlabyrinthesverursachen. 